\title{
Aqueous extract of bitter leaf Vernonia amygdalina Delile (Asterales: Asteraceae) ameliorates testosterone-induced benign prostatic hyperplasia (BPH) in Wistar rats
}

\author{
Abayomi Ajayi ${ }^{1}{ }^{*}$, Titilayo Ige ${ }^{2}$, Nich Arawa Ude ${ }^{1}$, Olusegun Dare \\ Omotoso $^{1}$, Gbenga Olorunshola Alege ${ }^{3}$, John Oluwagbenga Balogun ${ }^{4}$, \\ Ekanem Ikanna Asuquo ${ }^{5}$ and Akpovughaye Taiga ${ }^{2}$
}

${ }^{1}$ Department of Anatomy. Faculty of Basic Medical Sciences. College of Health Sciences. Kogi State University Anyigba. PMB 1008. Anyigba. Kogi State. Nigeria. *Email: abajayi2003@yahoo.com.

${ }^{2}$ Department of Biological Sciences. Faculty of Natural Sciences. Kogi State University. Anyigba. Kogi State. Nigeria.

${ }^{3}$ Department of Biological Sciences. Faculty of Sciences. Federal University Lokoja. Kogi State. Nigeria.

${ }^{4}$ Department of Chemistry. Faculty of Science. Obafemi Awolowo University. Ile-Ife. Osun State. Nigeria.

${ }^{5}$ Department of Anatomy. Faculty of Basic Medical Sciences. College of Health Sciences. University of Uyo. Akwa-Ibom State. Nigeria.

\begin{abstract}
Benign prostatic hyperplasia (BPH) is an age-dependent condition involving prostate enlargement which may lead to lower urinary tract symptoms (LUTS). This study was designed to study the ameliorative effect of the aqueous extract of bitter leaf Vernonia amygdalina Delile (Asterales: Asteraceae) on testosterone-induced $\mathrm{BPH}$ in a rat model. Thirty adult male Wister rats were randomly divided into six groups (A to F), with BPH induced through a single subcutaneous injection of $5 \mathrm{mg} / \mathrm{kg}$ of testosterone propionate (TP) and Vernonia amygdalina administered in various doses through oral gavage for 14 days. Group A (control) was administered with distilled water only, group B with $5 \mathrm{mg} / \mathrm{kg}$ of TP only, group C with $5 \mathrm{~g} / \mathrm{mL}$ of $V$. amygdalina only, group D with $5 \mathrm{mg} / \mathrm{kg}$ of TP and $5 \mathrm{~g} / \mathrm{mL}$ of $V$. amygdalina, group E with $5 \mathrm{mg} / \mathrm{kg}$ of TP and $7.5 \mathrm{~g} / \mathrm{mL}$ of $V$. amygdalina and group F with $5 \mathrm{mg} / \mathrm{kg}$ of TP and $10 \mathrm{~g} / \mathrm{ml}$ of $V$. amygdalina. Results show that testosterone caused histological changes that are similar to the presentation of BPH in the prostate. Aqueous extract of $V$. amygdalina was observed to ameliorate testosterone-induced histological changes and prostatic parameters especially at higher concentration. This suggests that bitter leaf could be a candidate herb for the treatment of BPH.
\end{abstract}

Keywords: Benign prostatic hyperplasia; Testosterone; Bitter leaf; Vernonia amygdalina; Prostate gland.
Received March 8, 2017

Accepted June 24, 2017

Released June 30, 2017

Open Acess Full Text Article

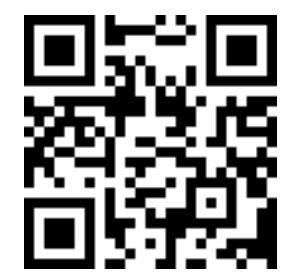

ORCID

(1) 0000-0001-8181-7407 Abayomi Ajayi

(D) 0000-0002-7111-8095 Titilayo Ige

(1) 0000-0003-2979-1283 Nich Arawa Ude 


\section{Introduction}

is an age-dependent, non-malignant condition that is characterised by prostate enlargement, which may lead to a plethora of urinary problems known as lower urinary tract symptoms (LUTS) (Chan, 2011). Prostate enlargement occurs through the rapid increment of the smooth muscle and epithelial cells within the transition zone of the prostate which results in the compression of the urethra, thus resulting in restricted urine flow (Kapoor, 2012). BPH has significant effect on the quality of life and is common among men over 50 years of age (Chou, 2007). Its prevalence shows that between the ages of 50-60 years, 50\% of men are affected while $90 \%$ of men above 80years old have this condition (Chan, 2011). It has also been observed that the chances of prostate cancer occurring in males increase with age similar to that of BPH (Suzuki, 2009).

Vernonia amygdalina Delile, commonly called bitter leaf belongs to the family Asteraceae, tribe Vernonieae and it is widely distributed in Nigeria (Hutchinson and Dalziel, 1963). The plant is a perennial shrub or small tree, usually cultivated for its leaf as vegetable, medicinal, traditional and domestic uses. The leaves have a very bitter taste, due to its chemical contents (Lasekan et al., 1998), which are responsible for its medicinal and anti-microbial properties (Rice-Evans et al., 1996; Okoh et al., 1995). Herbal preparations made from leaves of

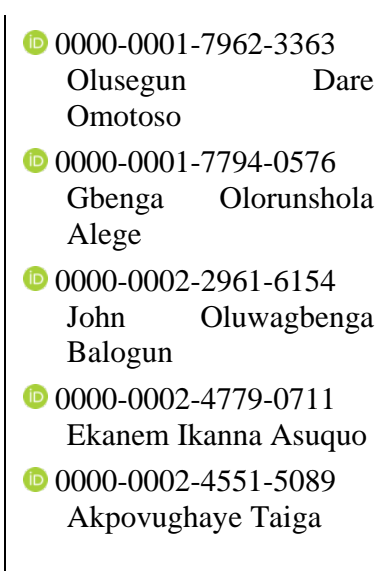

bitter leaf are used in curing ailments such as malaria, measles, dysentery, onchocerciasis, yellow fever, constipation, stomach pain, etc, while slender roots and stem branches of the plant are used as chewing stick that are very effective in dental care (Oluwalana and Adekunle, 1998). Herbal preparations of various forms are prepared from different parts of bitter leaf plant, but the easiest form is the fresh leaf extract, which is prepared by squeezing the leaves in water. The leaf extract is usually taken raw by people at an unregulated rate, depending on the severity of the ailment (Eisenberg et al., 1993). Bitter leaf is probably the most used medicinal plant in the genus Vernonia. Bitter leaf extracts may help suppress, delay or kill cancerous cell in many ways, such as induction of apoptosis as determined in cell culture and animal studies, enhance chemotherapy sensitivity, inhibition of the growth or growth signals of cancerous cells, suppression of metastasis of cancerous cells in the body by the inhibition of an antiapoptotic transcription factors as demonstrated in animal studies and reduction of oestrogen level in the body by the suppression of aromatase activity (Erasto et al., 2006).

The plant, bitter leaf, is a multipurpose plant that has a lot of potential valuable uses yet to be harnessed by the rural population in Nigeria. The objective of this study is to investigate the effect of bitter leaf extract on hormone-induced $\mathrm{BPH}$ in rats. 


\section{Materials and methods}

\section{Chemical and reagent}

Testosterone propionate injection was procured from Kuzak Pharmaceutical Store opposite Good Shepherd Hospitals, Anyigba, Kogi State, Nigeria.

\section{Collection and preparation of bitter leaf extract}

The plant Vernonia amygdalina (bitter leaf) was harvested from the Faculty of Agricultural Sciences Garden in Kogi State University, Anyigba. The gathered fresh Vernonia leafs were weighed in the histology laboratory, Department of Anatomy, and was grinded into powder before filter. The powder was further dissolved in $20 \mathrm{~mL}$ of distilled water, packaged in various containers and kept in the refrigerator at $4{ }^{\circ} \mathrm{C}$.

\section{Animals}

Thirty (30) adult male Wistar rats weighing about $120 \mathrm{~g}-180 \mathrm{~g}$ were obtained from the Animal Unit of Physiology
Department, Kogi State University. They were acclimatized for one week and exposed to free access of food and water ad libithum at standard laboratory condition of light and temperature. They were kept in a well partitioned, six-room wooden cage with iron mesh doors.

\section{Experimental design}

A total of 30 rats were divided into 6 groups ('A' to ' $F$ ') of 5 animals each by random selection. Group A was the placebo group, which was fed with vital feed in pellets and distilled water. Group B, apart from normal feeds, was administered with $5 \mathrm{mg} / \mathrm{kg}$ testosterone propionate (TP) only, aseptically by subcutaneous injection. Group C was given $1.5 \mathrm{~mL}$ bitter leaf only at a concentration of $5 \mathrm{~g} / \mathrm{mL}$. This was administered by oral gavage. Group D, E and $\mathrm{F}$ were given both testosterone $(5 \mathrm{mg} / \mathrm{kg})$ and $1.5 \mathrm{~mL}$ bitter leaf at $5 \mathrm{~g} / \mathrm{mL}$ $7.5 \mathrm{~g} / \mathrm{mL}$ and $10 \mathrm{~g} / \mathrm{mL}$, respectively. Animals' body weights were measured on the first day of the experiment (day 1), day 10 and on the last day (day 14).

Table 1. Treatment administration to experimented animals.

\begin{tabular}{|l|l|l|l|l|l|l|}
\hline Group & \multicolumn{1}{|c|}{ A } & \multicolumn{1}{c|}{ B } & \multicolumn{1}{c|}{ C } & \multicolumn{1}{c|}{ D } & \multicolumn{1}{c|}{ E } & \multicolumn{1}{c|}{ F } \\
\hline Feed & $\begin{array}{l}\text { Vital feed and } \\
\text { distilled water }\end{array}$ & $\begin{array}{l}\text { Vital feed and } \\
\text { distilled water }\end{array}$ & $\begin{array}{l}\text { Vital feed and } \\
\text { distilled water }\end{array}$ & $\begin{array}{l}\text { Vital feed and } \\
\text { distilled water }\end{array}$ & $\begin{array}{l}\text { Vital feed and } \\
\text { distilled water }\end{array}$ & $\begin{array}{l}\text { Vital feed and } \\
\text { distilled water }\end{array}$ \\
\hline Treatment & Placebo group & $\begin{array}{l}\text { Testosterone } \\
\text { propionate only }\end{array}$ & Bitter leaf only & $\begin{array}{l}\text { Bitter leaf and } \\
\text { testosterone }\end{array}$ & $\begin{array}{l}\text { Bitter leaf and } \\
\text { testosterone }\end{array}$ & $\begin{array}{l}\text { Bitter leaf and } \\
\text { testosterone }\end{array}$ \\
\hline $\begin{array}{l}\text { Testosterone } \\
\text { administration }\end{array}$ & Nil & $5 \mathrm{mg} / \mathrm{kg}$ & Nil & $5 \mathrm{mg} / \mathrm{kg}$ & $5 \mathrm{mg} / \mathrm{kg}$ & $5 \mathrm{mg} / \mathrm{kg}$ \\
\hline $\begin{array}{l}\text { Bitter leaf } \\
\text { administration }\end{array}$ & Nil & Nil & $1.5 \mathrm{~mL}(100 \mathrm{~g})$ & $1.5 \mathrm{~mL}(100 \mathrm{~g})$ & $1.5 \mathrm{~mL}(150 \mathrm{~g})$ & $1.5 \mathrm{~mL}(200 \mathrm{~g})$ \\
\hline $\begin{array}{l}\text { Concentration } \\
\text { of bitter leaf }\end{array}$ & Nil & Nil & $5 \mathrm{~g} / \mathrm{mL}$ & $5 \mathrm{~g} / \mathrm{mL}$ & $7.5 \mathrm{~g} / \mathrm{mL}$ & $10 \mathrm{~g} / \mathrm{mL}$ \\
\hline
\end{tabular}

\section{Animal sacrifice}

All animals (group A-F) were sacrificed on the 14th day of the experiment by cervical dislocation. The prostate gland was harvested, carefully weighed in all the groups and immediately fixed in 10\% formal saline as a preservative of choice for histological purpose. Blood sample was also collected by means of cardiac puncture.

\section{Results}

Weight changes in rats at the end of the experiment are presented in Table 2. Analysis of the weight changes (Table $3 \mathrm{e}$ 4) shows that on day one, the control group (group A) had the lowest weight of $98.00 \pm 6.83$ g while group $\mathrm{E}$ had the highest weight of $141.00 \pm 11.92 \mathrm{~g}$. Group E animals were administered with $2 \mathrm{~mL}$ of testosterone and $7.5 \mathrm{~g} / \mathrm{mL}$ of bitter leaf. 
However, the weight of group E animals was not significantly different from those of groups $\mathrm{D}$ and $\mathrm{F}$ which received $5 \mathrm{~g} / \mathrm{mL}$ and $10 \mathrm{~g} / \mathrm{mL}$ of bitter leaf respectively. On the last day of the experiment (day 14), weights of the rats still followed the same trends, with group $\mathrm{E}$ animals having the highest weight of $163.50 \pm 9.81 \mathrm{~g}$, followed by group D (150.75 $\pm 19.28 \mathrm{~g})$, which got $2 \mathrm{~mL}$ of testosterone and $5 \mathrm{~g} / \mathrm{mL}$ of bitter leaf and group F (146.25 $\pm 5.90 \mathrm{~g}$ ), which got $2 \mathrm{~mL}$ of testosterone and $10 \mathrm{~g} / \mathrm{mL}$ of bitter leaf. The control rats (group A) still had the least weight of $98.50 \pm 7.42 \mathrm{~g}$ on the last day. Weights of rats on day 14 across the groups are significantly different except between group B $(128.75 \pm 5.25 \mathrm{~g})$, which got $2 \mathrm{~mL}$ of testosterone only and group $\mathrm{C}$ (131.00 $\pm 6.68 \mathrm{~g})$, which got bitter leaf only.

Table 2. Weight changes in Wistar rats.

\begin{tabular}{|l|c|c|c|c|c|c|}
\hline & Group A & $\begin{array}{l}\text { Group B } \\
\text { Testosterone } \\
\text { only }\end{array}$ & $\begin{array}{l}\text { Group C } \\
\text { Bitter } \\
\text { leaf only }\end{array}$ & $\begin{array}{l}\text { Group D } \\
\text { Testosterone+ } \\
\text { Bitter leaf }\end{array}$ & $\begin{array}{l}\text { Group E } \\
\text { Testosterone+ } \\
\text { Bitter leaf }\end{array}$ & $\begin{array}{l}\text { Group F } \\
\text { Testosterone+ } \\
\text { Bitter leaf }\end{array}$ \\
\hline Day 1 & 97 & 112 & 123 & 157 & 157 & 139 \\
& 101 & 110 & 148 & 136 & 136 & 121 \\
& 105 & 126 & 126 & 129 & 129 & 150 \\
& 89 & 114 & 118 & 142 & 142 & 115 \\
\hline Day 10 & 100 & 126 & 126 & 134 & 143 & 113 \\
& 89 & 124 & 125 & 170 & 158 & 138 \\
& 107 & 129 & 134 & 164 & 157 & 146 \\
& 98 & 136 & 139 & 139 & 141 & 151 \\
& 102 & 135 & 133 & 131 & 151 & 140 \\
\hline Day 14 & 105 & 138 & 128 & 162 & 145 & 135 \\
& 116 & 125 & 122 & 131 & 150 & 136 \\
& 121 & 123 & 140 & 166 & 163 & 142 \\
& 102 & 125 & 125 & 166 & 145 & 150 \\
\hline
\end{tabular}

Table 3. Weight of prostate gland across groups.

\begin{tabular}{cccccccccccc}
\hline \multicolumn{2}{c}{ Group A } & \multicolumn{2}{c}{ Group B } & \multicolumn{2}{c}{ Group C } & \multicolumn{2}{c}{ Group D } & \multicolumn{2}{c}{ Group E } & \multicolumn{2}{c}{ Group F } \\
\hline A/W & P/W & A/W & P/W & A/W & P/W & A/W & P/W & A/W & P/W & A/W & P/W \\
\hline 105 & 1.12 & 138 & 0.41 & 128 & 0.16 & 162 & 0.91 & 145 & 0.50 & 135 & 0.32 \\
116 & 0.12 & 125 & 0.51 & 122 & 0.16 & 131 & 0.62 & 150 & 0.39 & 156 & 0.43 \\
121 & 0.13 & 123 & 0.49 & 140 & 0.17 & 166 & 0.49 & 163 & 0.51 & 134 & 0.32 \\
102 & 0.12 & 125 & 0.51 & 125 & 0.16 & 166 & 0.46 & 145 & 0.50 & 142 & 0.42 \\
105 & 0.12 & 124 & 0.52 & 124 & 0.16 & 164 & 0.46 & 150 & 0.32 & 151 & 0.40 \\
110 & 0.12 & 127 & 0.36 & 128 & 0.16 & 158 & 0.59 & 151 & 0.44 & 144 & 0.38 \\
\hline
\end{tabular}

Group $\mathrm{A}=$ Placebo, Group $\mathrm{B}=$ Testosterone, Group $\mathrm{C}=$ Bitter leaf only, Group $\mathrm{D}=$ Testosterone + Bitter leaf, Group E=Testosterone+Bitter leaf, Group $\mathrm{F}=$ Testosterone + Bitter leaf, A/W = Animal weight, $\mathrm{P} / \mathrm{O}=$ Prostate organ. 
Table 4. Effect of bitter leaf on prostatic parameters.

\begin{tabular}{lcccc}
\hline Groups & $\begin{array}{c}\text { Animal weight } \\
\text { at day 1 } \mathbf{( g )}\end{array}$ & $\begin{array}{c}\text { Animal weight } \\
\text { at day 14 }(\mathrm{g})\end{array}$ & $\begin{array}{c}\text { Mean prostate } \\
\text { specific antigen } \\
(\text { PSA) }(\mathbf{m g} / \mathrm{mL})\end{array}$ & $\begin{array}{c}\text { Prostrate weight } \\
(\mathrm{g})\end{array}$ \\
\hline $\mathrm{A}$ & $98.00 \pm 6.83^{\mathrm{c}}$ & $98.50 \pm 7.42^{\mathrm{d}}$ & $0.912 \pm 0.02^{\mathrm{c}}$ & $0.122 \pm 0.004^{\mathrm{c}}$ \\
$\mathrm{B}$ & $115.75 \pm 7.14^{\mathrm{b}}$ & $128.75 \pm 5.25^{\mathrm{c}}$ & $0.360 \pm 0.01^{\mathrm{f}}$ & $0.488 \pm 0.449^{\mathrm{b}}$ \\
$\mathrm{C}$ & $117.00 \pm 9.49^{\mathrm{b}}$ & $131.00 \pm 6.68^{\mathrm{c}}$ & $0.419 \pm 0.02^{\mathrm{e}}$ & $0.162 \pm 0.045^{\mathrm{c}}$ \\
$\mathrm{D}$ & $128.8 \pm 13.25^{\mathrm{ab}}$ & $150.75 \pm 19.28^{\mathrm{ab}}$ & $1.471 \pm 0.43^{\mathrm{a}}$ & $0.588 \pm 0.192^{\mathrm{a}}$ \\
$\mathrm{E}$ & $141.00 \pm 11.92^{\mathrm{a}}$ & $163.50 \pm 9.81^{\mathrm{a}}$ & $1.169 \pm 0.02^{\mathrm{b}}$ & $0.444 \pm 0.085^{\mathrm{b}}$ \\
F & $131.25 \pm 16.13^{\mathrm{ab}}$ & $146.25 \pm 5.90^{\mathrm{b}}$ & $0.431 \pm 0.20^{\mathrm{d}}$ & $0.378 \pm 0.540^{\mathrm{b}}$ \\
LSD & 6.14 & 9.24 & 0.19 & 0.08 \\
\hline
\end{tabular}

A - Control, B - Testosterone, C - Bitter Leaf, D - Testosterone (2 mL) + Bitter Leaf (5 g/mL), E - Testosterone $(2 \mathrm{~mL})+$ Bitter Leaf $(7.5 \mathrm{~g} / \mathrm{mL}), \mathrm{F}$ - Testosterone $(2 \mathrm{~mL})+$ Bitter Leaf $(10 \mathrm{~g} / \mathrm{mL})$, LSD-Least significant difference.

The prostate specific antigen (PSA) values when analysed show that group $\mathrm{D}$ rats had the highest PSA of $1.471 \pm 0.43 \mathrm{mg} / \mathrm{mL}$, which was significantly higher than the rest. This is followed by group $\mathrm{E}$ rats $(1.169 \pm 0.02 \mathrm{mg} / \mathrm{mL})$ while group B had the least PSA of $0.360 \pm 0.01 \mathrm{mg} / \mathrm{mL}$. Similarly, group $\mathrm{D}$ rats showed the highest prostate weight of $0.588 \pm 0.192 \mathrm{~g}$ which was significantly different $(p<0.05)$ from the other groups. Following after group D in terms of prostate weight are group $\mathrm{B}$ $(0.488 \pm 0.449 \mathrm{~g})$, group $\mathrm{E}(0.444 \pm 0.085 \mathrm{~g})$ and group $\mathrm{F}(0.378 \pm 0.540 \mathrm{~g})$.

Histological analysis shows that animals in group A (placebo) as well as group $\mathrm{C}$ appeared to have normal histological features of the prostate. Group $B$ showed glandular hyperplasia and nodulas which are papilated and thrown into folds in foci. These are typical features of BPH. Group D with low dose of $5 \mathrm{~g} / \mathrm{ml}$ of bitter leaf was observed to present with the most severe degeneration of prostate tissue, whereas group E showed moderate hypertrophy of the glands with inflammatory cell infiltrates. Group F showed unremarkable glandular epithelia and stroma of the prostate.

\section{Discussion}

$\mathrm{BPH}$ affects ageing men and there is need to find alternative therapies, especially in the face of an increasing ageing population that may be averse to surgery. Plant and dietary sources are potential elements in the management of $\mathrm{BPH}$ as shown in this study. Aqueous extract of bitter leaf was administered in three regimes; low, intermediate and high dose which corresponds to $5 \mathrm{~g} / \mathrm{ml}$ (group D), $7.5 \mathrm{~g} / \mathrm{ml}$ (group E) and $10 \mathrm{~g} / \mathrm{ml}$ (group F) of aqueous extract of bitter leaf. Results indicate the highest PSA level was recorded in animals that got low dose of bitter leaf. This suggests that aqueous extract of bitter leaf might have some effect on PSA levels in rats. Although PSA levels may not be an indicator for the development of BPH, high PSA levels in man might be indicative of prostate cancer (Onyechi et. al., 2012).

Structurally, the most severe histological damage to the prostate gland, sequel to testosterone-induced $\mathrm{BPH}$, was witnessed in animals taking low dose of bitter leaf. Degeneration of glands, epithelia and stroma of prostate tissue was massive in the low dose group, whereas the 

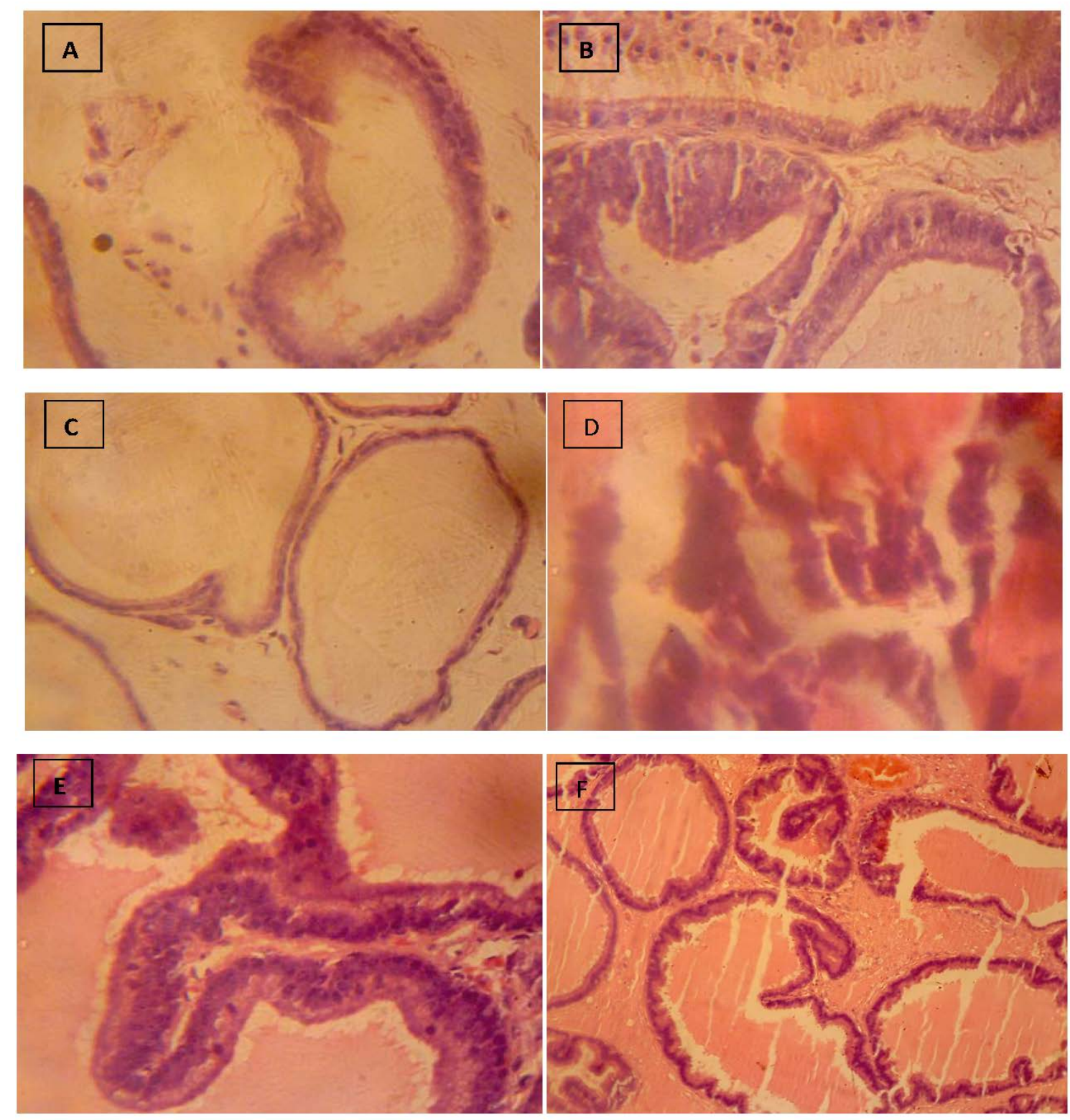

Figure 1. Histology of prostate gland. Prostate gland showing in group (A) normal glandular histology, group (B) glandular hyperplasia and nodulas accompanied by atrophy of the intervening fibromuscular stroma of the glands, group (C) normal histology, group (D) degenerated and hypertrophic structure, group (E) moderate hypertrophy with inflammatory cell infiltrate and group (F) moderate hypertrophy. H \& E stain. Magnification 40x.

intermediate group showed moderate hypertrophy of the glands with inflammatory cell infiltrates, an indication of recovery. The high dose group showed unremarkable glandular epithelia and stroma distortion and prostate weight in this group is lower than the those of intermediate and low dose groups, the former being the highest. This observation suggests that bitter leaf could have ameliorating effect on BPH in a dosedependent manner. This is consistent with previous reports that found bitter leaf to have (Onyechi et. al., 2012). Bitter leaf contains a number of compounds, which include proteins, fibre, carbohydrate, 
chlorophyll, hemicellulose, ascorbic acid, carotenoid, calcium, iron, phosphorus, potassium, sulphur, sodium, manganese, copper, zinc, magnesium and selenium, stigmastane-type saponins, steroidal saponins, sesquiterpene lactones, flavonoids, terpenese, coumarins, phenolic acids, lignans, xanthones, anthraquinones and peptides (Okoli et al., 2007; Eleyinmi et al., 2008). Although the particular compound that may be responsible for the effect of the aqueous extract of bitter leaf on BPH remains unknown, we speculate that phytoestrogens might have played a role. Phytoestrogens have been said to be beneficial in the management of $\mathrm{BPH}$ due to their affinity for estrogen beta receptor (Abraham and Ajayi, 2014) and they are present in bitter leaf in form of lignans and flavonoids. Moreover, sesquiterpene lactones contained in bitter leaf may suppress aromatase activity thereby reducing the level of oestrogen in the body (Erasto et al., 2006). Apart from the beneficial effects bitter leaf has on the prostate, as shown by this study, the plant has also been shown to significant antiparasitic, antibacterial, platelet antiaggregating and cytotoxic activity (Ijeh and Ejike, 2011). Hence, Vernonia amygdalina has a lot of medicinal uses.

Although surgery remains the most effective treatment for cases of severe symptoms BPH, pharmacological treatment can also be used to treat or manage severe symptoms cases (Dhingra and Bhagwat, 2011). Aqueous extract of bitter leaf may therefore complement standard pharmacological treatment and possibly used as prophylactic.

\section{Conclusion}

Bitter leaf is beneficial for the treatment of enlarged prostrate (BPH) in rat, especially at high concentration. Hence, hormone-induced prostate enlargement in adult male may be reduced by oral administration of fresh bitter leaf extract. It is recommended that prophylactic use of bitter leaf for BPH be studied as well as clinical trials, to validate the efficacy of bitter leaf extract in the treatment of enlarge prostate in man.

\section{Conflicts of interest}

Authors declare that they have no conflict of interests.

\section{References}

Abraham, K.; Ajayi, A. Benign prostatic hyperplasia: role of estrogen and putative therapeutic effect of selective estrogen receptor modulators. Proceedings of the Physiological Society of Nigeria, 28, 2014. Available from: $<$ http://www.physoc.org/proceedings/abstract/Pr oc Physiol Soc 31C55>. Accessed on: 20 Feb., 2017.

Chan, S. W. Pathology and medical therapy of benign prostatic hyperplasia. The Hong Kong Medical Diary, v. 16, no. 6, p. 4-8, 2011. https://dx.doi.org/10.4236/ojmm.2015.51004

Chou, C.-L. Current medical treatment for benign prostatic hyperplasia/lower urinary tract symptoms. Incont Pelvic Floor Dysfunct, v. 1, no. 2, Suppl. 2, p. 15-19, 2007. Available from: $<$ http://www.tcs.org.tw/issue/folder/1_2suppl/1suppl 2-15-19.pdf>. Accessed on: 20 Feb., 2017.

Dhingra, N.; Bhagwat, D. Benign prostatic hyperplasia: an overview of existing treatment. Indian Journal of Pharmacology, v. 43, no. 1, p. 6-12, 2011. https://dx.doi.org/10.4103/02537613.75657

Eisenberg, D. M.; Kessler, R. C.; Foster, C.; Norlock, F. E., Calkins, D. R.; Delbanco, T. L. Unconventional medicine in the United States. New England Journal of Medicine, v. 328, p. 246-252, 1993. https://dx.doi.org/10.1056/NEJM199301283280 406

Eleyinmi, A. F.; Sporns, P.; Bressler, D. C. Nutritional composition of Gongronema latifolium and Vernonia amygdalina. Nutr. Food Sci., v. 38, p. 99-109, 2008. https://dx.doi.org/10.1108/00346650810862975

Erasto, P.; Grierson, D. S.; Afolayan, A. J. Bioactive sesquiterpene lactones from the leaves of Vernonia amygdalina. J. Ethnopharmacol., v. 106, p. 117-120, 2006. https://dx.doi.org/10.1016/j.jep.2005.12.016

Hutchinson, J.; Dalziel, M. J. Floral of West Tropical Africa. 2. ed. London: Crown Agent for Overseas Government and Administrations, 1963. v. 2 p. $225-297$. 
Ijeh, I. I.; Ejike, C. E. C. C. Current perspectives on the medicinal potentials of Vernonia amygdalina Del. Journal of Medicinal Plants Research, v. 5, no. 7, p. 1051-1061, 2011. Available from: $<$ http://www.academicjournals.org/article/articl e1380529017_Ijeh and Ejike.pdf $>$. Accessed on: 20 Feb., 2017.

Kapoor, A. Benign Prostatic Hyperplasia (BPH) management in the primary care setting. The Canadian Journal of Urology, v. 19, no. 1, p. 10-17, 2012. Available from: <http://www.canjurol.com/html/freearticles/V19I5S1F-03-DrKapoor.pdf>. Accessed on: 20 Feb., 2017.

Lasekan, O. O.; Lasekan, W. O.; Babalola, J. O. Effect of Vernonia amygdalina (bitter leaf) extract on brewing qualities and amino acid profiles of stout drink from sorghum and barley malts. Food Chemistry, v. 64, p. 507-510, $1998 . \quad$ https://dx.doi.org/10.1016/S03088146(98)00148-4

Okoh, I. A.; Babalola, G. O.; Ilori, M. O. Effect of methanol extract of Vernonia amygdalina on malting and brewing properties of sorghum. Tech. Q. Master Brew. Assoc. Am., v. 32, no. 1, p. 11-14, 1995.

Okoli, R. I.; Aigbe, O.; Ohafu-Obode, J. O.; Mensah, J. K. Medicinal herbs used for managing some common ailments among Esan People Edo State, Nigeria. Pakistan Journal of Nutrition, v. 6, no. 5, p. 470-490, 2007. https://dx.doi.org/10.3923/pjn.2007.490.496
Oluwalana, S. A.; Adekunle, M. F. Forest plant roots in household nutrition and health care in Abeokuta, Ogun State, Nigeria. J. Trop. for Resources, v. 1, p. 120-136, 1998.

Onyechi, O.; Elom, S.O.; Chukwunonso E. C. C. Prostate problems with aging, prevention and treatment prospects. Unique, p. 45-50, 2012.

Rice-Evans, C. A.; Miller, N. J.; Paganga, G. Structure-antioxidant activity relationships of flavonoids and phenolic acids. Free Radic. Biol. Med., v. 20, p. 933-956, 1996. https://doi.org/10.1016/0891-5849(95)02227-9

Suzuki, K. Epidemiology of prostate cancer and benign prostatic hyperplasia. Journal of Medical Association of Japan, v. 52, no. 6, p. 478-483, 2009. Available from: $<$ https://www.med.or.jp/english/journal/pdf/200 9_06/478_483.pdf $>$. Accessed on: 20 Feb., 2017.

License information: This is an open-access article distributed under the terms of the Creative Commons Attribution License, which permits unrestricted use, distribution, and reproduction in any medium, provided the original work is properly cited. 